\title{
Is Grant-Aid More Effective than Concessional Loans? Evidence from a Dynamic Panel of Sub-Saharan African Countries
}

\author{
Anupam Das (Corresponding author) \\ Department of Policy Studies, Mount Royal University \\ 4825 Mount Royal Gate SW, Calgary T3E 6K6, Canada \\ E-mail: adas@mtroyal.ca \\ Syeed Khan \\ Department of Economics, University of Manitoba \\ 15 Chancellors Circle, Winnipeg R3T 5V5, Canada \\ E-mail: umkhan6@cc.umanitoba.ca
}

Received: September 5, 2011

Accepted: September 20, 2011

Published: January 1, 2012

doi:10.5539/ijef.v4n1p14

URL: http://dx.doi.org/10.5539/ijef.v4n1p14

\begin{abstract}
Despite being one of the highest aid recipient regions, the growth performance in Sub-Saharan Africa (SSA) has been rather disappointing. In this paper, we answer two questions. 1) Is there any significant impact of foreign aid on economic growth? 2) Is grant more effective than loans in promoting growth? To answer these questions, we employ a GMM technique for a panel of 27 SSA countries over the period of 1961 to 2009 . By using this technique, we are able to control for endogeneity that may arise from explanatory variables. Our results suggest that grant aid is more effective than concessional loans. On average, aggregate aid's effect on economic growth is not discernable from zero in SSA countries. These questions are important for policymakers of SSA who often face the dilemma of high aid but low growth.
\end{abstract}

Keywords: Grant, Loans, Foreign aid, Growth, GMM

\section{Introduction}

Despite being one of the largest recipients of foreign aid or official development assistance (ODA), the growth performance in Sub-Saharan Africa (SSA) has not been outstanding in last few decades (see table 1 for a comparison between SSA, South Asian (SA) and Low and Middle Income (LMI) countries). Abrupt growth performance in SSA put forward the dispute about aid potency, especially on economic performance. Economists have long tried to find out whether ODA is effective to promote economic growth in this region. The answer, however, remains inconclusive in the literature. In recent years, Ndambendia and Njoupouognigni (2010) and Rotarou and Ueta (2009) found strong and positive relationships between aid and economic growth. On the other hand, while Mallik (2008) found a negative relationship between ODA and growth in SSA countries, Bezuidenhout (2009) found no significant interaction between these two variables.

The apparent failure for perceiving any irrefutable association between aid and economic growth is possibly due to a number of reasons including sample selection, model specification bias and failure to disentangling the effectiveness of various components of foreign aid. Hansen and Tarp (2000) carefully diagnosed 72 studies on aid-growth relationship to ascertain the conceptual, econometric and data difficulties with cross-country analysis. They concluded that the model misspecification and small sample of countries could be held responsible for inconclusive results on aid effectiveness. Another major drawback of aid growth literature is to treat different components of ODA as one. While developing countries receive different components of ODA (mainly in the form of concessional loans and grant-aid) separately under discrete conditions, failure to disaggregate these components may impose a serious restriction on econometric outcomes (Chang et al., 2002). Loxley and Sackey (2008) correctly identified that the grant component of aid was more effective than concessional loans to promote economic growth in SSA. Moreover, it should be noted that future debt servicing obligations are entailed only by concessional loans and not by grant-aid (Loxley and Sackey, 2008: 191). Thus, differentiated treatment to different components of ODA is crucial as grant-aid and concessional loans may behave differently in promoting economic growth. 
The above explanation is more credible for SSA countries since for a long period of time most of theses countries were carrying high and increasing debt levels. Donor countries often generate new loans for debtor countries ${ }^{1}$. In such a situation, a portion of loan may not be available for domestic resource mobilization. In other words, this amount of concessional loans does not contribute to economic growth in developing countries.

To that end, the primary purpose of this paper is to identify the growth effects of disaggregated ODA in 27 SSA countries over the period of 1961 to 2009 (See table 2 for the list of these countries). We measure the impact of concessional loans and grant-aid on economic growth, while controlling for all other external inflows in both cases. This is done in three steps. First, we employ the Maddala and Wu (1999) panel unit root (based on Fisher (1932)) tests to identify the level of integration. Our results suggest that the variables under consideration do not contain unit roots. Second, we exercise the first differenced generalized method of moments (GMM) procedure proposed by Arellano and Bond (1991) to examine the individual impact of concessional loans and grant-aid on economic growth. Finally, we use the same first differenced GMM technique to identify the aggregate impact of ODA on economic growth. By using GMM estimation method we are able to capture the effect of lagged dependent variable (lagged GDP growth) on economic growth and control for endogeneity that may arise from explanatory variables.

The rest of the paper is organized in the following manner. We review the relevant literature in Section 2. Section 3 discusses both the theoretical and empirical methodology to be used in the paper. Section 4 presents results, and finally, section 5 concludes the paper.

\section{Literature Review}

The two-gap model of Chenery and Strout (1966) was the first theoretical model that attempted to explain the importance of foreign aid in developing countries. Developing countries typically face two types of constraints, i.e. savings constraint and foreign exchange constraint. This creates a two-fold problem. First, enough savings is not generated for domestic investment and second, countries fail to buy intermediate goods required for development due to insufficient amount of foreign currency. Chenery and Strout (1966) argued that foreign aid could help to remove both these gaps by providing foreign exchange. Indeed, the basic assumption of this model is that all aid should be diverted to the investment sector. Opposing this view, Griffin and Enos (1970), Griffin (1970), Weisskopf (1972) argued that foreign aid could substitute domestic resources since the marginal cost of aid was much lower than the marginal return of domestic investment. Thus, aid could be used to increase consumption instead of increasing investment. In such a situation, aid will not be sufficient to ease the savings constraint, and therefore, aid may not lead to economic growth in developing countries.

Confounding theoretical results motivated researchers to examine aid-growth relationship with empirical dataset. Over the last fifty years, Solow-type (1956) neoclassical growth models remained the central framework to analyze this relationship. The voluminous empirical literature (based on either Solow-type or close mimic of Slow-type framework) on ODA and growth relationship helped a lot to understand how and why foreign aid might have an effect on economic growth, but helped a little to find any conclusive results. Doucouliagos and Paldam (2008 and 2009) conducted a number of meta-studies to examine the aid-growth nexus. In Doucouliagos and Paldam (2008), 543 aid-growth regressions were analyzed from 68 papers published before January 2007. 94 out of those 543 estimates used Solow-type regression models. Overall results however were sadly inconclusive (Doucouliagos and Paldam, 2009). While analyzing the regional differences in the aid-growth association, Doucouliagos and Paldam (2008) did not find any direct effect of aid on economic growth in African countries. Thus, the literature on aid effectiveness failed to prove any effect of aid on economic growth that was statistically significantly larger than zero (Doucouliagos and Paldam, 2008: 18)

While Doucouliagos and Paldam (2008) found a disappointing effect of aid on growth, they also argued that few individual country studies found larger effects than what was evident in their meta-study. For example, Odusayana et al. (2011) used the error-correction technique for Nigeria over the period of 1981 to 2008 and found a positive effect of aid on growth both in the short run and long run. Similar results were found by Rotarou and Ueta (2009) for Tanzania. In contrast, Mallik (2008) found a negative long run aid-growth relationship for Central African Republic, Malawi, Mali, Sierra Leone and Togo.

Based on the above literature review, the causal relationships could be different partly because of insufficient data points. Given most of the papers used data only for 25 to 35 years, low statistical testing power from time series estimations were not surprising. Therefore, researchers in recent years focused on using panel estimation procedures to compensate for the deficiency of an inadequate sample size. Unfortunately, Africa-based literature on panel estimates for aid growth relationships is still not conclusive. Ndambendia and Njoupouognigni (2010) conducted pooled mean group (PMG) and fixed effect methods for 36 SSA countries from 1980 to 2007 and found a positive aid-growth association. Using a panel cointegration technique, Irandoust and Ericsson (2005) also found similar 
results for Africa. Bezuidenhout (2009), however, employed a GMM technique and found an insignificant aid-growth link for 17 Southern African countries from 1990 to 2005.

One important similarity across most of the papers is that aggregated aid was used for the analysis. However, separating aid into its different components may shed more light on the current debate since the impact of aid on economic growth may be different for different components. Loxley and Sackey (2008) found the grant component of aid to be more productive because the loan component of aid suffers from debt servicing constraint. Kosac and Tobin (2006) also argued that different forms of aid could be used for different purposes (for government consumption, to compensate for a fall in exports or to accommodate any foreign reserve deficiency) and hence the impact on growth would be different. Doucouliagos and Paldam (2011) had the most recent and striking results from their meta-analysis. In contrast to their previous argument from Doucouliagos and Paldam (2008 and 2009), they found significant and robust results when ODA was disaggregated into different components. Taking more than 20 studies, they found that grant and project aid had positive effects on economic growth while technical and program aid had a negative one. Therefore, recognizing differential impacts of aid components on growth is important to get the true picture of aid-growth nexus.

Another important issue, often ignored in aid-growth analysis, is the concern about simultaneity bias due to potential endogeneity of aid. Rajan and Subramanian (2008) severely criticized different techniques of determining aid-growth relationship as most of the studies failed to acknowledge the endogeneity within the framework. With their proposed technique, which accounted for endogeneity bias, they found no robust relationship between foreign aid and economic growth.

To contribute to the prevailing controversy, our study attempts to accommodate all of these caveats discussed above. This study uses the first differenced GMM estimation procedure to control for endogeneity within the model. We also use disaggregated aid data to capture the differential impact of aid components on economic growth. Finally, we ensure the best usage of the longest available data coverage to capture the true variability across countries.

\section{Theoretical and Econometric Methodology}

\subsection{Data and Behavioral Equations}

We use different modified versions of the famous neoclassical growth equation proposed by Solow (1956). The first behavioral equation (equation 1) examines the role of concessional loans on GDP growth, where GDP growth $\left(g_{Y}\right)$ is primarily determined by investment (inv) and the growth in labor force $\left(g_{L}\right)$. It is well established in the existing literature that the output series is often persistent (Alesina et al., 1996 and Bond et al., 2001). Thus, current year's growth is influenced by last year's growth. To accommodate the persistence characteristic of this variable we include lagged GDP growth $\left(g_{Y-I}\right)$ as an independent variable. The growth in concessional loans $\left(g_{C L}\right)$ is included in the behavioral equation to estimate its effect on output growth. Finally, growth in other external flows $\left(g_{O E F C L}\right)$ (all other external flows but concessional loans) is included to avoid any bias that may arise from the problem of omitted variables.

$$
g_{Y}=f\left(g_{Y-1}, i n v, g_{L}, g_{C L}, g_{O E F C L}\right)
$$

Concessional loan is replaced by grant-aid $\left(g_{G A}\right)$ and $g_{O E F C L}$ is replaced by $g_{O E F G A}$ (all other external flows but grant-aid) in equation 2 to identify their growth effect. Finally, equation 3 is used to identify the effect of aggregate ODA (that includes both loans and grants) on economic growth. Growth in ODA $\left(g_{O D A}\right)$ is used instead of $g_{C L}$ or $g_{G A}$. All other external flows but ODA is represented as $g_{O E F O D A}$.

$$
\begin{gathered}
g_{Y}=f\left(g_{Y-1}, i n v, g_{L}, g_{G A}, g_{O E F G A}\right) \\
g_{Y}=f\left(g_{Y-1}, i n v, g_{L}, g_{O D A}, g_{O E F O D A}\right)
\end{gathered}
$$

Behavioral equations specified in equations 1,2 and 3 are estimated using panel data covering 27 SSA countries for the period of 1961 to 2009. In above equations, investment is defined as the growth of capital formation. Other external flows for loans, grants and ODA are calculated by deducting that particular variable from total receipt. Since the data on labor force growth is not available for most of the SSA countries, following Das and Paul (2011), we use a proxy of this variable, which is calculated as the number of people belonging to the age group of 15 to 64 years old. Investment, labor force and output data are collected from World Development Indicators and UN Data published by the World Bank and the United Nations respectively. Data on ODA, loans, grants and other external flows are acquired from the OECD Statistical Database.

\subsection{Testing for Integration}

Most macroeconomic variables with a large $T$ are characterized by unit-root processes (Nelson and Plosser, 1982). In our dataset, $N$ is 27 and $T$ is 49 . Therefore, the likelihood of non-stationarity of some of the variables could be an issue. To determine whether non-stationarity is a legitimate concern, researchers have conducted a number of unit 
root tests. One popular test due to Im et al. (1997) proposes a test statistics based on averaging individual Dickey-Fuller unit root tests $\left(t_{i}\right)$ where $t_{i}$ is defined as $N^{-1} \sum_{i=1}^{N} t_{i}$. The test statistics $t_{I M}$ is:

$$
t_{I M}=\frac{\sqrt{N}\left(\bar{t}-E\left[t_{i} \mid \rho_{i}=0\right]\right)}{\sqrt{\operatorname{var}\left[t_{i} \mid \rho_{i}=0\right]}} \rightarrow N(0,1)
$$

While the Im et al. (1997) tests are successful in relaxing the assumption of homogeneity of the roots across the units, there are number of difficulties that are not addressed by these tests. First, these tests assume that $T$ is the same for all the cross section units and therefore, $E\left[t_{i} \mid \rho_{i}=0\right]$ and $\operatorname{var}\left[t_{i} \mid \rho_{i}=0\right]$. Second, Im et al. (1997) allow for a limited amount of cross-correlation across units by allowing for common time effects. Maddala and Wu (1999) however argue that in many real-life applications the cross-correlations may not take this simple form (Banerjee, 1999). Instead, they developed a new unit root tests based on Fisher (1932), which assumed that all series are non-stationary under the null hypothesis against the alternative that at least one series in the panel is stationary. The test statistics is given by $P=-2 \sum_{i=1}^{N} \ln p_{i}$ and combines $p$-values from $N$ independent augmented Dickey-Fuller unit root tests. The $P$ test is distributed as $\chi^{2}$ with degrees of freedom twice the number of cross section units. Unlike Im et al. (1997), Maddala and Wu (1999) test does not require a balanced panel. We, therefore, use Maddala-Wu tests to identify the level of integration of our time series variables. Results (presented in table 3 ) indicate that the null hypothesis of unit root for all variables is strongly rejected at the 1 percent level.

Based on the results from unit root tests, we proceed with the first-differenced GMM approach to examine the growth effect of foreign aid. There are several other reasons why GMM technique is the most appropriate estimation procedure for this purpose. First, estimation using pooled cross-section and time series data allows us to use more data points, and thus, exploit the time series characteristic of different relationships. Second, GMM procedure controls for country-specific effect, which otherwise becomes a part of the error term. Finally, we are able to capture the potential endogeneity that may arise from all explanatory variables.

\subsection{First-differenced GMM}

Consider the following $A R(1)$ model with unobserved country-specific effects:

$$
y_{i, t}=\alpha y_{i, t-1}++\varsigma_{i}+\tau_{i, t}
$$

Where $i=1,2, \ldots, N$ and $t=2, \ldots, T \cdot \varsigma_{i}$ is the component for the time invariant country-specific effect and $\tau_{i, t}$ is the time variant component, where $\varepsilon_{i, t}=\varsigma_{i}+\tau_{i, t}$ has the standard error component structure,

$$
E\left[\varsigma_{i}\right]=0, E\left[\tau_{i, t}\right]=0 \text { and } E\left[\varsigma_{i} \tau_{i, t}\right]=0 \text { for } i=1,2, \ldots, N \text { and } t=2, \ldots, T
$$

The GMM dynamic panel estimator makes two assumptions. (i) Transient errors are serially uncorrelated.

$$
E\left[\tau_{i, t} \tau_{i, s}\right]=0 \text { for } i=1,2, \ldots, N \text { and } s \neq t
$$

And (ii) the explanatory variables are not correlated with future realizations of the error term.

$$
E\left[y_{i, t} \tau_{i, t}\right]=0 \text { for } i=1,2, \ldots, N \text { and } t=2, \ldots, T
$$

Under assumptions (7) and (8), we have the following moment conditions:

$$
E\left[y_{i, t-s} \Delta \tau_{i, t}\right]=0 \text { for } t=3, \ldots, T \text { and } s \geq 2, \ldots,(T-1)
$$

These are the moment restrictions exploited by the standard linear first-differenced GMM estimator. This procedure thus allows us to use the lagged levels dated $t-2$ and earlier as instruments (Bond et al., 2001).

\section{Results and Discussion}

Results from estimating panel equation 1, 2 and 3 are presented in table 4 . While the first two equations estimate the effect of loans and grants respectively on economic growth, the third equation deals with the aggregate ODA growth. In all these, the Hansen J-statistics of over-identifying restrictions do not reject the hypothesis that instruments are valid and exogenous.

As anticipated, the coefficient for the lagged growth rate is very significant (at better than the 1 percent level) in all three equations and extremely robust to change in any specification. The magnitudes of these coefficients are 0.29 , 0.23 and 0.26 respectively. This proves the persistence hypothesis of the output growth variables as suggested by Alesina et al. (1996). Positive coefficients for investment are also significant at the 1 percent level in all three equations. Growth of labor force is neither significant nor possess the expected sign in any of the three equations. It 
should however be noted that the rate of growth of economically active population has been used as a proxy for this variable. Thus, this variable should be considered with a large error (Das, 2010).

From the equation 1, neither growth in concessional loans, nor growth in other external flows (all other foreign flows but concessional loans) is found to be significant, suggesting that the growth rate of GDP is not responsive to growth in concessional loans or other external flows. In equation 2, we examine the effect of growth in grant-aid on economic growth. The coefficient for grant-aid is 0.28 . This variable is significant at the 1 percent level and insensitive to the change in specification. This suggest that, on average, one unit of increase in grant flow increases the GDP growth rate by 0.28 units in SSA countries over the period of 1961 to 2009. Essentially, this result resembles the findings of Doucouliagos and Paldam (2011). Growth of all other external flows but grant-aid is significant at the 5 percent level. The negative coefficient of this variable suggests an inverse movement of growth rates due to any increase in other external flows. Finally, similar to concessional loans, growth in ODA is also found to be insignificant in equation 3 where we attempt to identify the effect of aggregate ODA on GDP growth in SSA countries. Thus, on average, the effect of ODA on GDP growth can be statistically discernable from zero. Our result on the growth effect of ODA is similar to the one found by Bezuidenhout (2009). All other external flows (including other capital flows and current transfers) are found to be extremely significant (at better than the 1 percent level) in the equation 3. This result suggests that capital flows (other than foreign aid) and current transfers together affect economic growth positively in SSA countries. It would appear, from these results, that grants have been more effective than loans in Africa in terms of promoting economic growth. Overall effect of ODA tends to be statistically insignificant. We thus hypothesize that the insignificant impact of concessional loans on economic growth is due the future debt servicing obligations entailed with loans. Thus, following Loxley and Sackey (2008), we also argue that SSA countries may need to strategize to reduce future dependence on concessional loans.

\section{Conclusion}

Sub-Saharan Africa (SSA) being one of the highest aid-recipient regions in the world has not been able to register remarkable output growth in last few decades. Is there any significant impact of ODA in SSA? Moreover, given different components of ODA have different impacts on economic growth, it is also important to identify the effect of disaggregated aid on GDP growth. This study attempts to provide answers to these questions by using the first-differenced GMM technique to a panel of 27 SSA countries.

The relationship between ODA and economic growth is rather inconclusive. Our estimation results suggest that, on average, aid has no significant impact in SSA over the period of 1961 to 2009. When the total amount of aid is divided into concessional loans and grant-aid, we found grant-aid is significant while concessional-loans are not. Based on these results, we hypothesize that the insignificant relationship between concessional loans and GDP growth may be due the future debt servicing obligations entailed with loans. These finding thus imply that donors should help the SSA countries by providing more grants than loans. From the recipients' point of view, loans should be channeled to those sectors which are productive and therefore, should complement the current investment and attract new investment.

This study also raises important additional questions: 1) is aid also insignificant in promoting growth in the long run? 2) does the aid-growth (and disaggregated aid-growth) relationship hold for other developing regions in the world? 3) although grant aid is found to be significant, are there any differential impacts of other components of grant aid? These questions are important and thus, left for future research.

\section{Acknowledgement}

We wish to thank Dr. John Serieux, Cindy Xu and anonymous referees for useful comments and suggestions.

\section{References}

Alesina, A., Özler, S., Roubini, N., \& Swagel, P. (1996). Political Instability and Economic Growth. Journal of Economic Growth, 1(2), 189-211.

Arellano, M., \& Bond, S. (1991). Some Tests of Specification for Panel Data: Monte Carlo Evidence and an Application to Employment Equations. Review of Economic Studies, 58(2), 277-297, http://dx.doi.org/10.2307/2297968

Banerjee, A. (1999). Panel Data Unit Roots and Cointegratio: An Overview. Oxford Bulletin of Economics and Statistics, Special Issue, 607-629, http://dx.doi.org/10.1111/1468-0084.61.s1.12

Bond, S., Hoeffler, A, \& Temple, J. (2001). GMM Estimation of Empirical Growth Model. CEPR Discussion Paper. No. 3048. http://ssrn.com/abstract $=290522$.

Bezuidenhout, H. (2009). A Regional Perspective on Aid and FDI in Southern Africa. International Advances in 
Economic Research, 15, 310-321.

Chang, C. C., Fernandez-Arias, E., \& Servén, L. (2002). Measuring Aid Flows: A New Approach. Global Economy Quarterly, 3(2), 197-218.

Chenery, H. B., \& Strout, A. M. (1966). Foreign Assistance and Economic Development. American Economic Review, 56, 679-733.

Das, A., \& Paul, B. (2011). Openness and Growth in Emerging Asian Economies: Evidence from GMM Estimations of a Dynamic Panel. Economics Bulletin, 31(3), 2219-28.

Das, A. (2010). Three Essays on Non-Market Financial Flows to Developing Countries. Thesis Dissertation. University of Manitoba.

Doucouliagos, H., \& Paldam, M. (2011). The Effectiveness of Development Aid on Growth: An Update. European Journal of Political Economy, 27, 399-404, http://dx.doi.org/10.1016/j.ejpoleco.2010.11.004

Doucouliagos, H., \& Paldam, M. (2009). The Aid Effectiveness Literature: The Sad Results of 40 Years of Research. Journal of Economic Surveys, 23(3), 433-461, http://dx.doi.org/10.1111/j.1467-6419.2008.00568.x

Doucouliagos, H., \& Paldam, M. (2008). Aid Effectiveness on Growth: A Meta Study. European Journal of Political Economy, 24, 1-24, http://dx.doi.org/10.1016/j.ejpoleco.2007.06.002

Doucouliagos, H., \& Paldam, M. (2006). Aid Effectiveness on Accumulation: A Meta Study. Kyklos, 59(2), 227-254, http://dx.doi.org/10.1111/j.1467-6435.2006.00326.x

Fisher, R. A. (1932). Statistical Methods for Research Workers, (4 ${ }^{\text {th }}$ ed.). Edinburgh: Oliver and Boyd.

Griffin, K. B. (1970). Foreign Capital, Domestic Savings and Economic Development. Bulletin of the Oxford University Institute of Economics and Statistics, 32(2), 99-112, http://dx.doi.org/10.1111/j.1468-0084.1970.mp32002002.x

Griffin, K. B., \& Enos, J. L. (1970). Foreign Assistance: Objectives and Consequences. Economic Development and Cultural Change, 18(3), 313-327, http://dx.doi.org/10.1086/450435

Hansen, H., \& Tarp, F. (2000). Aid Effectiveness Disputed. Journal of International Development, 12, 375-398, http://dx.doi.org/10.1002/(SICI)1099-1328(200004)12:3<375::AID-JID657>3.0.CO;2-M

Im, K. S., Pesaran, M. H., \& d Shin, Y. (1997). Testing for Unit Roots in Heterogeneous Panels. Mimeo. Department of Applied Economics. University of Cambridge.

Irandoust, M., \& Ericsson, J. (2005). Foreign Aid, Domestic Savings, and Growth in LDCs: An Application of Likelihood-Based Panel Cointegration. Economic Modeling, 22, 616-627, http://dx.doi.org/10.1016/j.econmod.2004.03.004.

Kenen, P. B. (1990). Organizing Debt Relief: the Need for a New Institution. The Journal of Economic Perspectives, 4(1), 7-18.

Kosack, S., \& Tobin, J. (2006). Funding Self-Sustaining Development: the Role of Aid, FDI and Government in Economic Success. International Organization, 60, 205-243.

Loxley, J., \& Sackey, H. (2008). Aid Effectiveness in Africa. African Development Review, 20(2), 163-199, http://dx.doi.org/10.1111/j.1467-8268.2008.00181.x

Maddala, G. S., \& Wu, S. (1999). A Comparative Study of Unit Root Tests with Panel Data and a New Simple Test. Oxford Bulletin of Economics and Statistics, Special Issue, 631-652, http://dx.doi.org/10.1111/1468-0084.61.s1.13

Mallik, G. (2008). Foreign Aid and Economic Growth: A Cointegration Analysis of the Six Poorest African Countries. Economic Analysis and Policy, 38(2), 251-60. http://www.eap-journal.com.au/vol_38_iss_2.php.

Ndambendia, H. \& Njoupouognigni, M. (2010). Foreign Aid, Foreign Direct Investment and Economic Growth in Sub-Saharan Africa: Evidence from Pooled Mean Group Estimator (PMG). International Journal of Economics and Finance, 2(3), 39-45.

Nelson, C., \& Plosser, C. (1982). Trends and Random Walks in Macro Economic Time Series: Some Evidence and Implications. Journal of Monetary Economics, 10, 130-162.

Odusayana, I. A., Logile, A. I., \& Akanni, L. O. (2011). Foreign Aid, Public Expenditure and Economic Growth: The Nigerian Case. Journal of Applied Business Research, 27(3), 33-41.

Rajan, R. G.., \& Subramanian, A. (2008). Aid and Growth: What Does the Cross-Country Evidence Really Show? The Review of Economics and Statistics. 90(4), 643-665. 
Rotarou, E., \& Ueta, K. (2009). Foreign Aid and Economic Development: Tanzania's Experience with ODA. Kyoto Economic Review, 78(2), 157-189.

Solow, R. M. (1956). A Contribution to the Theory of Economic Growth. The Quarterly Journal of Economics. 70(1), 65-94, http://dx.doi.org/10.2307/1884513

Weisskopf, T. E. (1972). The Impact of Foreign Capital Inflow on Domestic Savings in Underdeveloped Countries. Journal of International Economics, 2, 25-38, http://dx.doi.org/10.1016/0022-1996(72)90043-8

World Bank. (2011). World Development Indicators. The World Bank.

\section{Notes}

Note 1. Kenen (1990) provided an interesting discussion on how new loans were provided by official donors to Bolivia and Mexico for the purpose of debt reduction.

Table 1. Foreign Aid Flows and Growth Rates across Different Regions (1961 to 2009)

\begin{tabular}{ccccccccc}
\hline & \multicolumn{2}{c}{$1961-79$} & \multicolumn{2}{c}{$\mathbf{1 9 8 0 - 1 9 8 9}$} & \multicolumn{2}{c}{$\mathbf{1 9 9 0 - 1 9 9 9}$} & \multicolumn{2}{c}{$\mathbf{2 0 0 0 - 2 0 0 9}$} \\
\hline & ODA/GNI & Growth & ODA/GNI & Growth & ODA/GNI & Growth & ODA/GNI & Growth \\
\hline SSA & 2.45 & 4.34 & 4.08 & 2.15 & 5.58 & 2.04 & 4.99 & 4.60 \\
SA & 2.42 & 4.49 & 1.69 & 5.55 & 1.32 & 5.32 & 0.83 & 6.74 \\
LMI & 1.10 & 5.30 & 1.17 & 3.40 & 1.21 & 3.45 & 0.91 & 5.80 \\
\hline
\end{tabular}

Source: World Bank (2011)

Table 2. List of Countries in the Dataset

\begin{tabular}{ccc}
\hline Benin & Ghana & Republic of the Congo \\
Botswana & Kenya & Senegal \\
Burkina Faso & Lesotho & Sierra Leone \\
Burundi & Madagascar & Swaziland \\
Cameroon & Malawi & Tanzania \\
Central African Republic & Mali & The Gambia \\
Chad & Mauritania & Togo \\
Cote d'Ivoire & Niger & Uganda \\
Gabon & Nigeria & Zambia \\
\hline
\end{tabular}

Table 3. Results from Fisher Type Stationarity Tests Proposed by Maddala and Wu (1999)

\begin{tabular}{ccc}
\hline Variables & Test Statistics & Determination \\
\hline$g_{Y}$ & $850.43^{* * *}(0.000)$ & Strongly Stationary \\
$i n v$ & $1127.74 * * *(0.000)$ & Strongly Stationary \\
$g_{L}$ & $321.33^{* * *}(0.000)$ & Strongly Stationary \\
$g_{C L}$ & $1199.53^{* * *}(0.000)$ & Strongly Stationary \\
$g_{G A}$ & $978.52^{* * *}(0.000)$ & Strongly Stationary \\
$g_{O D A}$ & $1159.50^{* * *}(0.000)$ & Strongly Stationary \\
$g_{O E F C L}$ & $1140.95^{* * *}(0.000)$ & Strongly Stationary \\
$g_{O E F G A}$ & $1125.46^{* * *}(0.000)$ & Strongly Stationary \\
$g_{O E F O D A}$ & $1046.75^{* * *}(0.000)$ & Strongly Stationary \\
\hline
\end{tabular}

Notes: 1) Null Hypothesis: Full panel contains unit roots. 2) $P$-values are in parentheses. 3) $* * *$ implies significance at the 1 percent level. 
Table 4. Effects of Concessional Loans and Grant-aid on GDP Growth

\begin{tabular}{|c|c|c|c|}
\hline \multicolumn{4}{|l|}{ Dependent Variable: $g_{Y}$} \\
\hline Explanatory Variables & Equation 1 with $g_{C L}$ & Equation 2 with $g_{G A}$ & Equation 3 with $g_{O D A}$ \\
\hline$g_{Y-1}$ & $0.291 * * *(0.090)$ & $0.231 * * *(0.086)$ & $0.260 * * *(0.085)$ \\
\hline inv & $0.052 * * *(0.010)$ & $0.048 * * *(0.010)$ & $0.510 * * *(0.009)$ \\
\hline$g_{L}$ & $-0.479(0.615)$ & $-0.414(0.615)$ & $-0.540(0.625)$ \\
\hline$g_{C L}$ & $0.001(0.001)$ & - & - \\
\hline$g_{O E F C L}$ & $0.123(0.057)$ & - & - \\
\hline$g_{G A}$ & - & $0.276 * * *(0.090)$ & - \\
\hline$g_{O E F G A}$ & - & $-0.003 * *(0.001)$ & - \\
\hline$g_{O D A}$ & - & - & $0.084(0.189)$ \\
\hline$g_{O E F O D A}$ & - & - & $0.025 * * *(0.009)$ \\
\hline Hansen J-Statistics & & & \\
\hline $\begin{array}{c}\text { (Over-identification test for all } \\
\text { instruments) }\end{array}$ & $4.579(P$-value: 0.711$)$ & 4.70 ( $P$-value: 0.697$)$ & 4.321 ( $P$-value: 0.742$)$ \\
\hline Number of Groups & 27 & 27 & 27 \\
\hline Number of Observations & 400 & 403 & 393 \\
\hline
\end{tabular}

Notes: 1) Standard errors are in parentheses. 2) ${ }^{* * *}$ and $* *$ indicate significance at the 1 percent level. And $5 \%$ level respectively. 